University of Nebraska - Lincoln

DigitalCommons@University of Nebraska - Lincoln

\title{
Effects of the antimicrobial tylosin on the microbial community structure of an anaerobic sequencing batch reactor
}

\author{
Toshio Shimada \\ University of Illinois at Urbana-Champaign \\ Xu Li \\ University of Nebraska - Lincoln, xuli@unl.edu \\ Julie L. Zilles \\ University of Illinois at Urbana-Champaign \\ Eberhard Morgenroth \\ Swiss Federal Institute of Aquatic Science and Technology, Dubendorf \\ Lutgarde Raskin \\ University of Michigan, Ann Arbor, raskin@umich.edu
}

Follow this and additional works at: https://digitalcommons.unl.edu/civilengfacpub

Part of the Civil Engineering Commons

Shimada, Toshio; Li, Xu; Zilles, Julie L.; Morgenroth, Eberhard; and Raskin, Lutgarde, "Effects of the antimicrobial tylosin on the microbial community structure of an anaerobic sequencing batch reactor" (2010). Civil Engineering Faculty Publications. 37.

https://digitalcommons.unl.edu/civilengfacpub/37

This Article is brought to you for free and open access by the Civil Engineering at DigitalCommons@University of Nebraska - Lincoln. It has been accepted for inclusion in Civil Engineering Faculty Publications by an authorized administrator of DigitalCommons@University of Nebraska - Lincoln. 


\title{
Effects of the antimicrobial tylosin on the microbial community structure of an anaerobic sequencing batch reactor
}

\author{
Toshio Shimada, ${ }^{1} \mathrm{Xu} \mathrm{Li},{ }^{2}$ Julie L. Zilles, ${ }^{1}$ Eberhard Morgenroth, ${ }^{3,4}$ and Lutgarde Raskin ${ }^{5}$ \\ 1. Department of Civil and Environmental Engineering, University of Illinois at Urbana-Champaign, Urbana, Illinois, USA \\ 2. Department of Civil Engineering, University of Nebraska-Lincoln, Lincoln, Nebraska, USA \\ 3. Eawag: Swiss Federal Institute of Aquatic Science and Technology, Dubendorf, Switzerland \\ 4. Institute of Environmental Engineering, ETH Zurich, Zurich, Switzerland \\ 5. Department of Civil and Environmental Engineering, University of Michigan, USA
}

Corresponding author - Lutgarde Raskin, Department of Civil and Environmental Engineering, University of Michigan, 107 EWRE Building, 1351 Beal Ave, Ann Arbor, Michigan 48109-2125; tel 734 647-6920, fax 734 763-2275, email raskin@umich.edu

\begin{abstract}
The effects of the antimicrobial tylosin on a methanogenic microbial community were studied in a glucosefed laboratory-scale anaerobic sequencing batch reactor (ASBR) exposed to stepwise increases of tylosin (0, 1.67 , and $167 \mathrm{mg} / \mathrm{L}$ ). The microbial community structure was determined using quantitative fluorescence in situ hybridization (FISH) and phylogenetic analyses of bacterial 16S ribosomal RNA (rRNA) gene clone libraries of biomass samples. During the periods without tylosin addition and with an influent tylosin concentration of $1.67 \mathrm{mg} / \mathrm{L}, 16 \mathrm{~S}$ rRNA gene sequences related to Syntrophobacter were detected and the relative abundance of Methanosaeta species was high. During the highest tylosin dose of $167 \mathrm{mg} / \mathrm{L}, 16 \mathrm{~S}$ rRNA gene sequences related to Syntrophobacter species were not detected and the relative abundance of Methanosaeta decreased considerably. Throughout the experimental period, Propionibacteriaceae and high GC Gram-positive bacteria were present, based on 16S rRNA gene sequences and FISH analyses, respectively. The accumulation of propionate and subsequent reactor failure after long-term exposure to tylosin are attributed to the direct inhibition of propionate-oxidizing syntrophic bacteria closely related to Syntrophobacter and the indirect inhibition of Methanosaeta by high propionate concentrations and low $\mathrm{pH}$.
\end{abstract}

Keywords: anaerobic, antimicrobial, macrolide, methanogenesis, propionate, tylosin

\section{Introduction}

The widespread use of antimicrobials has led to the detection of these chemical compounds in the environment (Koplin et al., 2002). Waste streams from hospitals, animal husbandry, and pharmaceutical production facilities contain elevated concentrations of antimicrobials (Campagnolo et al., 2002; Kummerer, 2001; Zilles et al., 2005) and are commonly treated in systems that rely on biological processes. Acceptable treatment performance has been reported in anaerobic lagoons treating manure with concentrations of antimicrobials that would inhibit sensitive microorganisms (Jindal et al., 2006; Zilles et al., 2005), but the mechanism(s) for maintaining biological activity in the presence of antimicrobials and the associated questions of how and when antimicrobial resistance develops are not well understood.

Tylosin, a commonly used veterinary antimicrobial, is a macrolide obtained from Streptomyces (McGuire et al., 1961). Macrolides inhibit protein synthesis by interacting with the $50 \mathrm{~S}$ subunit of the bacterial ribosome. Although macrolides are not expected to target methanogenic archaea (Auerbach et al., 2004; Garza-Ramos et al., 2001), the inhibition of anaerobic bacteria may result in indirect adverse effects on methanogenesis. Most Gram-negative bacteria are resistant to macrolides due to relative impermeability of the cellular outer membrane and active drug efflux systems (Nikaido, 1996). Resistance to macrolides in other organisms may result from target modification, enhanced drug efflux, and drug inactivation. The most widespread mechanism of macrolide resistance is target modification mediated by 
erythromycin ribosome methylase genes, which prevents macrolide, lincosamide, and type B streptogramin $\left(\mathrm{MLS}_{\mathrm{B}}\right)$ antimicrobials from binding to 23S ribosomal RNA (rRNA) (Jensen et al., 1999; Weisblum, 1995).

Previous studies of macrolide inhibition in anaerobic systems provide contradictory results, ranging from negligible effects (Camprubi et al., 1988; Chelliapan et al., 2006; Masse et al., 2000; Poels et al., 1984; Stone et al., 2009) to substantial decreases in treatment performance (Amin et al., 2006; Loftin et al., 2005; Sanz et al., 1996; Shimada et al., 2008a). In anaerobic batch tests, the addition of tylosin has inhibited acetate, propionate, and butyrate uptake (Amin et al., 2006; Sanz et al., 1996; Shimada et al., 2008a). To better understand the effects of tylosin on anaerobic treatment performance, we investigated what steps of the anaerobic food web are affected by tylosin and whether anaerobic activity in the presence of tylosin is due to antimicrobial resistant populations with similar function as the sensitive organisms or to the diversion of the electron flow to alternate pathways of the anaerobic food web.

We previously evaluated the effects of tylosin on the treatment performance and on specific steps in the anaerobic food web of a glucose-fed anaerobic sequencing batch reactor (ASBR) (Shimada et al., 2008a). At an influent concentration of $1.67 \mathrm{mg} / \mathrm{L}$, decreases in the rates of propionate uptake and methane production rates were observed without significant effects on chemical oxygen demand (COD) removal efficiency and total biogas production. At an influent concentration of $167 \mathrm{mg} / \mathrm{L}$, a decrease in the glucose uptake rate, the accumulation of acetate and propionate, and a marked decrease of reactor performance were observed. The observed inhibition was speculated to be due to direct effects of tylosin on butyrate- and propionate-oxidizing syntrophic bacteria and indirect effects of volatile fatty acid (VFA) accumulation on aceticlastic methanogens. However, the performance data and batch tests did not determine whether or not changes in the microbial community structure were occurring in the reactor, and the impact of tylosin on the prevalence of macrolide resistance was not evaluated in our previous work.

The purpose of the current study was to evaluate the effect of tylosin on the microbial community structure and the prevalence of antimicrobial resistance using fluorescence in situ hybridization (FISH) and 16S rRNA gene-directed clone library analyses.

\section{Materials and Methods}

\section{Laboratory-Scale ASBR}

Detailed information on the reactor setup, operation, and performance has been reported (Shimada et al., 2008a). In brief, a jacketed bioreactor with a 5-L working volume was inoculated using granular sludge from an upflow anaerobic sludge blanket reactor treating brewery wastewater and operated as an ASBR with 24-h cycles. The reactor was operated at $35^{\circ} \mathrm{C}$ with a hydraulic retention time (HRT) of 1.67 days, a solids retention time of 80 days, and an organic loading rate of $3.5 \mathrm{~kg} \mathrm{COD} /\left(\mathrm{m}^{3} /\right.$ day). During the feeding step, $70 \mathrm{~mL}$ of a concentrated influent solution containing glucose $(234.4 \mathrm{~g} / \mathrm{L})$ was mixed with $2.93 \mathrm{~L}$ of buffered dilution water and supplemented with vitamins and trace elements. The influent tylosin concentration was increased in a stepwise manner $(0 \mathrm{mg} / \mathrm{L}$ from days 0 to $749 ; 1.67 \mathrm{mg} / \mathrm{L}$ from days 750 to 944; and $167 \mathrm{mg} / \mathrm{L}$ from days 945 to 1,039), resulting in tylosin loading rates of 0,1 , and $100 \mathrm{mg} /(\mathrm{L} /$ day).

\section{FISH}

Sludge samples were collected from the middle level of the ASBR during mixing, fixed with $50 \%$ ethanol, and stored in phosphate-buffered saline (PBS)/ethanol (1:1) solution at $-20^{\circ} \mathrm{C}$. Fixed samples were dispersed using a Model 500 sonic dismembrator (Fisher Laboratory Equipment, Pittsburgh, PA) for $30 \mathrm{~s} \mathrm{(5} \mathrm{s} \mathrm{pulses} \mathrm{with} 7.5 \mathrm{~s}$ intervals). The sonication time was optimized as recommended by Zhou et al. (2007). Dispersed samples were diluted with sterile PBS, filtered through $0.2-\mathrm{mm}$ polycarbonate membranes (Poretics Corporation, Livermore, CA), and transferred to gelatin-coated slides (Amann et al., 1990). The slides were dehydrated in a graded ethanol series (50\%, 80\%, and 100\%; 3 min each) and air dried.

FISH was performed as previously described (De los Reyes et al., 1997; Zhou et al., 2009) using the oligonucleotide probes and formamide concentrations listed in Table I. The cells were stained on the slide with $1 \mu \mathrm{g} / \mathrm{mL}$ 4',6-diamidino-2-phenylindole (DAPI) (Sigma-Aldrich, St. Louis, MO) and citifluor (Marivac Limited, Halifax, NS, Canada) was used as antifading agent. The slides were observed under 630× magnification on a Zeiss Axiovert 100 inverted microscope (Carl Zeiss, Oberkochen, Germany) with appropriate filter sets and an exposure

Table I. Oligonucleotide probes, sequences, target groups, and formamide stringency used in this study.

\begin{tabular}{|c|c|c|c|c|}
\hline Probe & Sequence $\left(5^{\prime}-3^{\prime}\right)$ & Target & Formamide (\%) & Reference \\
\hline S-D-Bact-0338-a-A-18 (Bact0338) & GCTGCCTCCCGTAGGAGT & Most bacteria & 25 & Amann et al. (1990) \\
\hline L-P-Grps-1901-a-A-18 (HGC69a) & TATAGTTACCACCGCCGT & Actinobacteria & 25 & Roller et al. (1994) \\
\hline S-G-Clos-0129-a-A-15 (CLOSXIVa) & CTGTATGAGGCAGGT & Clostridia cluster XIVa & 30 & Weber et al. (2001) \\
\hline L-*-Bact-2053-a-A-13 $\left(\right.$ MLS $\left._{\mathrm{B}}\right)$ & CTGCCTTTCTGGG & $\mathrm{MLS}_{\mathrm{B}}$ sensitive bacteria & 12.5 & Zhou et al. (2009) \\
\hline S-S-Arch-0915-a-A-20 (Arch0915) & GTGCTCCCCCGCCAATTCCT & Most archaea & 20 Stah & 1 and Amann (1991) \\
\hline S-F-Msae-0825-a-A-23 (MX825) & TCGCACCGTGGCCGACACCTAGC & Methanosaeta & 40 & Raskin et al. (1994) \\
\hline S-G-Msar-0821-a-A-21 (MS821) & CGCCATGCCTGACACCTAGCGAGC & Methanosarcina & 50 & Raskin et al. (1994) \\
\hline
\end{tabular}


time of $1 \mathrm{~s}$ for FISH response. Images of duplicate wells (containing approximately 2,000 cells per well) were acquired from random locations using a Coolsnap color camera (Roper Scientific, Tucson, AZ). Automated image processing was performed using the software Visilog v6 (NOESIS, Gif sur Yvette, France) and classification was performed using fuzzy c-means clustering with manual quality control (Zhou et al., 2007).

$M_{\mathrm{B}} \mathrm{S}_{\mathrm{B}}$ resistance was quantified indirectly through hybridization of an oligonucleotide probe $\left(\mathrm{MLS}_{\mathrm{B}}\right.$ in Table I) to unmethylated, $\mathrm{MLS}_{\mathrm{B}}$-sensitive cells as described by Zhou et al. (2009). The prevalence of ribosomal methylation and presumed MLS $_{B}$ resistance was calculated by subtracting $\mathrm{MLS}_{\mathrm{B}}$ probe-positive cells from the Bact0338 count and normalizing to the Bact0338 count.

\section{Clone Library Construction}

ASBR sludge samples were pelleted in 2-mL microcentrifuge tubes and stored at $-80^{\circ} \mathrm{C}$. DNA was extracted using a FastDNA SPIN Kit (Qbiogene, Inc., Irvine, CA) and quantified using a NanoDrop ND1000 (NanoDrop Technology, Wilmington, DE). DNA extracts were visualized using electrophoresis on a $0.8 \%$ agarose gel. PCR targeting the $16 \mathrm{~S}$ rRNA gene of all bacteria was performed as described by Dojka et al. (2000) using primers 8f and 1492r (Richardson et al., 2002). Triplicate PCR products were pooled, purified by gel electrophoresis, and extracted using a MinElute Gel Extraction Kit (QIAGEN, Inc., Valencia, CA). Purified PCR products from Phase 1 (0 mg/L tylosin, day 743), Phase 2 (1.67 mg/L tylosin, days 841 and 939), and Phase 3 $(167 \mathrm{mg} / \mathrm{L}$ tylosin, day 1,030) were used to create clone libraries using a TOPO4 TA Cloning Kit (Invitrogen, Carlsbad, CA). One hundred ninety-two clones from each library were sequenced at the Genome Sequencing Center at Washington University (St. Louis, MO).

\section{Phylogenetic Analysis}

Sequences obtained from the forward (T3) and reverse (T7) sequencing primers were separately uploaded to the Ribosomal Database Project (RDP) II release 9.5 using the Pipeline function (Cole et al., 2007). Because of the lack of overlap between the sequences retrieved with the two primers, only the sequences from the $\mathrm{T} 7$ primer were used for the phylogenetic analysis (Table II). Even among T7 initiated sequences, 40, 18, 52, and 51 sequences of the four libraries could not be aligned properly in RDP Pipeline. Successfully aligned sequences were further classified using the default 80\% confidence threshold in RDP. Among them, a number of clones were classified as unidentified bacteria $(53,46,65$, and 20 clones for days 743 , 841,939 , and 1,030, respectively).

Phylogenetic trees were built for clones related to the phyla Actinobacteria, Firmicutes, and Proteobacteria.
Because there was no overlap between sequences obtained from the two primers, only the sequences originally amplified from the primer $1492 \mathrm{r}$ were used to build the phylogenetic trees. Clone sequences and the corresponding reference sequences were aligned using ClustalW (Chenna et al., 2003). All of the sequences passed the anomaly check in the program Mallard (Ashelford et al., 2006) and were used to constructed phylogenetic trees using the neighbor-joining algorithm in MEGA 4.0 (Tamura et al., 2007). Robustness was tested by bootstrap resampling from 1,000 replicates. All positions containing gaps and missing data were eliminated from the dataset. There are 245, 351, and 358 positions in the final datasets of Actinobacteria, Proteobacteria, and Firmicutes, respectively. Clones with sequence similarity higher than $95 \%$ were grouped into operational taxonomic units (OTU) (Fields et al., 2005). The software BioEdit was used to edit sequences during the phylogenetic analysis (Hall, 1999). The clones are available at GenBank with accession numbers GQ853694-GQ853879.

Table II. Classification and the relative abundance (\%) of the 16S rRNA gene sequences obtained from the reactor during different operational conditions.

\begin{tabular}{|c|c|c|c|c|}
\hline \multirow[b]{2}{*}{ Classification } & \multicolumn{3}{|c|}{ Tylosin concentration ${ }^{\mathrm{a}}$} & \multirow[b]{2}{*}{$\begin{array}{r}167 \\
\mathrm{mg} / \mathrm{L}\end{array}$} \\
\hline & $\begin{array}{r}0 \\
\mathrm{mg} / \mathrm{L}\end{array}$ & $\begin{array}{r}1.67 \\
\mathrm{mg} / \mathrm{L}-\mathrm{A}\end{array}$ & $\begin{array}{r}1.67 \\
\mathrm{mg} / \mathrm{L}-\mathrm{B}\end{array}$ & \\
\hline Actinobacteria & 26.3 & 34.9 & 6.7 & 69.4 \\
\hline Propionibacteriaceae & 5.0 & 8.7 & 2.7 & 17.4 \\
\hline Nocardioidaceae & 5.0 & 4.8 & 1.3 & 9.9 \\
\hline Bacteroidetes & 20.2 & 22.2 & 30.7 & 2.5 \\
\hline Rikenellaceae & 14.1 & 15.9 & 13.3 & 2.5 \\
\hline Prophyromonadaceae & 1.0 & n.d. & n.d. & n.d. \\
\hline Candidate Division OP10 & n.d. & 0.8 & n.d. & n.d. \\
\hline Candidate Division TM7 & 6.1 & 1.6 & n.d. & n.d. \\
\hline Chloriflexi & 8.1 & 12.7 & n.d. & n.d. \\
\hline Anaerolinaeceae & 1.0 & 0.8 & n.d. & n.d. \\
\hline Caldilineacea & 7.1 & 8.7 & n.d. & n.d. \\
\hline Firmicutes & 23.2 & 11.1 & 13.3 & 14.9 \\
\hline Insertae Sedis XV & 3.0 & 4.0 & n.d. & n.d. \\
\hline Ruminococcaceae & 1.0 & 1.6 & 2.7 & n.d. \\
\hline Clostridiaceae & 8.1 & n.d. & n.d. & n.d. \\
\hline Veillonellaceae & 9.1 & 4.0 & 9.3 & 2.5 \\
\hline Peptococcaceae & n.d. & n.d. & 1.3 & n.d. \\
\hline Enterococcaceae & n.d. & n.d. & n.d. & 12.4 \\
\hline Nitrospira & 2.0 & 4.0 & 44.0 & 5.8 \\
\hline Nitrospiraceae & 2.0 & 4.0 & 44.0 & 5.8 \\
\hline Proteobacteria & 12.1 & 12.7 & 5.3 & 5.8 \\
\hline Enterobacteriaceae & n.d. & n.d. & n.d. & 3.3 \\
\hline Syntrophobacteraceae & 8.1 & 9.5 & 4.0 & n.d. \\
\hline Syntrophobacter & 7.1 & 7.9 & 2.7 & n.d. \\
\hline Syntrophaceae & n.d. & 1.6 & n.d. & n.d. \\
\hline Methyloccystaceae & n.d. & n.d. & n.d. & 0.8 \\
\hline Desulfovibrionaceae & n.d. & n.d. & 1.3 & n.d. \\
\hline Vibrionaceae & n.d. & n.d. & n.d. & 1.6 \\
\hline Spirochaetes & 2.0 & 0.8 & n.d. & 1.6 \\
\hline Spirochaetaceae & 2.0 & 0.8 & n.d. & 1.6 \\
\hline Total identified clones & 99 & 126 & 75 & 121 \\
\hline
\end{tabular}

n.d., not detected.

a. The four samples were collected on days $743,841,939$, and 1,030 , respectively. 


\section{Mathematical Model}

The ASBR was modeled as described previously (Shimada et al., 2008b). In brief, the IWA Anaerobic Digestion No. 1 (Batstone et al., 2002) was modified to include microbial storage and tylosin inhibition. Tylosin inhibition was included by increasing the decay rate of propionate oxidizing syntrophic bacteria. The model was implemented in the software Aquasim 2.1e (Reichert, 1994).

The tylosin inhibition constant and the Monod parameters for propionate and acetate uptake were estimated based on measured concentrations throughout ASBR 24-h cycles. Parameter estimation was performed using a weighted least squares method. ADM1 recommended values (Batstone et al., 2002) were used for the Monod parameters of growth of all microbial populations and uptake of the other soluble substrates.

\section{Results and Discussion}

Detailed information on the reactor performance has been reported previously (Shimada et al., 2008a). During the periods with no tylosin addition and $1.67 \mathrm{mg} / \mathrm{L}$ tylosin (days 600-944), the reactor showed excellent biogas production (10.4 L/day) and COD removal (99.5\%) and low effluent VFA concentrations $(8.9 \mathrm{mg} / \mathrm{L}$ as acetate). The treatment performance deteriorated substantially after increasing the tylosin feed to $167 \mathrm{mg} / \mathrm{L}$ (days 945-1,050) with biogas production of $2.9 \pm 0.5 \mathrm{~L} /$ day, COD removal of $7.0 \%$, and effluent VFA concentrations of up to $3,400 \mathrm{mg} / \mathrm{L}$ as acetate.

\section{Domain-Level Community Structure}

The abundance of bacteria and archaea were quantified using FISH (Figure 1a). Prior to tylosin addition, bacteria represented $35.7 \pm 1.1 \%$ (mean \pm standard error) of the DAPI stained cells. Hybridization to the general bacterial probe (Bact0338) remained stable during the first 50 days of Phase 2 and then decreased to $23.1 \pm 0.7 \%$. The increase of the tylosin influent concentration to $167 \mathrm{mg} / \mathrm{L}$ was followed by an increase in the relative level of bacteria $(40.3 \pm 3.6 \%)$. Hybridization to the general archaeal probe (Arch0915) began at $18.6 \pm 0.5 \%$ but decreased to $12.7 \pm 1.1 \%$ prior to tylosin addition. The levels then remained relatively stable throughout reactor operation with averages of $14.3 \pm 0.5 \%$ during $1.67 \mathrm{mg} / \mathrm{L}$ tylosin addition and $13.5 \pm 0.9 \%$ during $167 \mathrm{mg} / \mathrm{L}$ tylosin addition.

Together, hybridization to the general bacterial and archaeal probes accounted for $51.2 \pm 2.9 \%, 43.0 \pm 3.0 \%$, and $53.8 \pm 6.6 \%$ of the DAPI stained cells for Phase 1, Phase 2 , and Phase 3, respectively. A protocol using paraformaldehyde as fixative (De los Reyes et al., 1997) was also tested but did not increase the total number of cells hybridized to the Bact0338 and Arch0915 probes. The relatively low number of hybridized cells may be due to the presence of inactive cells (i.e., low ribosome content) inside the granules. Large zones of DAPI stained cells without hybridization to general microbial probes have been observed in anaerobic granules previously and were attributed to substrate limitations at the center and low $\mathrm{pH}$ close to the surface of the granules (Batstone et al., 2004). Alternatively, it may reflect incomplete coverage of this microbial community by the Bact0338 probe, as a mixture of probes has been recommended to obtain a more complete bacterial count (Daims et al., 1999).

Due to the relatively low percentage of hybridized cells, the results were normalized to the total number of cells that hybridized to the oligonucleotide probes Bact0338 and Arch0915 for comparison with literature values (Figure 2a). Throughout the experimental period, the relative levels of bacteria and archaea (normalized to Bact0338 and Arch0915) were within the broad range reported in previous studies. Liu et al. (2002) reported that bacterial and archaeal cells comprised $40.8 \%$ and

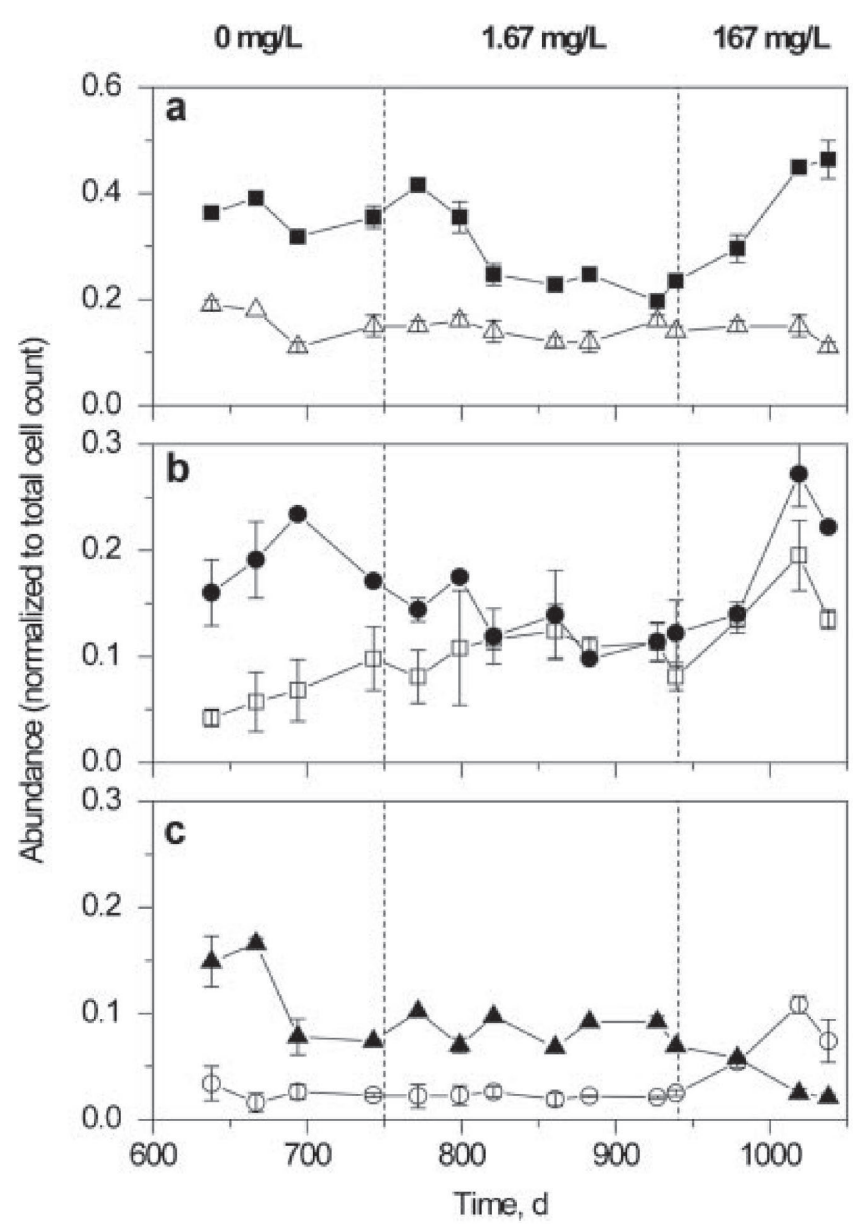

Figure 1. Fraction of microbial cells that hybridized to oligonucleotide probes targeting all bacteria $(\mathbf{\square})$ and all archaea $(\Delta)$ (panel a), high GC bacteria $(\bullet)$ and clostridia cluster XIV ( $\square$ ) (panel b), and Methanosaeta ( $\mathbf{\Delta})$ and Methanosarcina (०) (panel c) in ASBR biomass. The results were normalized to total cell counts with DAPI. Data points and error bars represent mean values and half ranges of duplicate wells, respectively. Numbers above the figure indicate influent tylosin concentrations. 

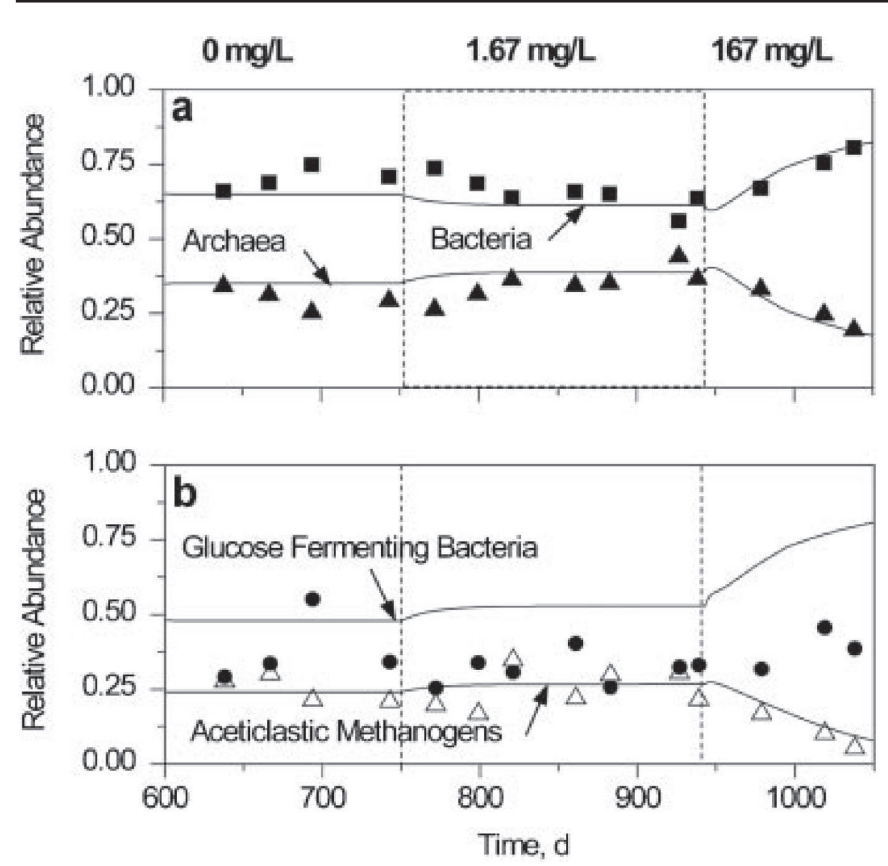

Figure 2. Modeled (-) and measured bacteria $(\boldsymbol{\bullet})$, archaea $(\boldsymbol{\Delta})$, high GC bacteria $(\bullet)$, and aceticlastic methanogens (Methanosarcina + Methanosaeta, $\Delta$ ) relative abundance in the ASBR throughout the experimental period. FISH data were normalized to total hybridization (sum of Bact0338 and Arch0915). Numbers above the figure indicate influent tylosin concentrations.

$62.9 \%$, respectively, in granular biomass samples from a UASB reactor treating brewery wastewater, based on membrane hybridizations. Zheng et al. (2006) reported that methanogenic archaea comprised $40 \%$ of the microbial community in a glucose-fed reactor, also based on membrane hybridizations. Sekiguchi et al. (1998) analyzed the phylogenetic diversity of granules from a mesophilic reactor fed with sucrose, acetate, and propionate and reported that $81 \%$ of the clones were affiliated with bacteria and $19 \%$ with archaea.

\section{Bacterial Community Structure}

The bacterial community structure was monitored throughout the reactor operation at a coarse level of resolution using FISH (Figure 1b). Most of the bacteria (55$100 \%)$ were Gram-positive and belonged to the phyla Actinobacteria (HGC probe) and Firmicutes (ClosXIVa probe). The abundance of Actinobacteria (normalized to DAPI) was $19.2 \pm 1.5 \%, 11.8 \pm 1.0 \%$, and $24.7 \pm 2.5 \%$ during Phase 1, Phase 2 (days 799-944), and Phase 3 (days 1,009-1,039), respectively. Clostridium cluster XIVa increased $(4.2 \pm 0.8 \%$ to $9.8 \pm 3.0 \%)$ throughout Phase 1 and remained stable $(10.4 \pm 0.7 \%)$ throughout Phase 2 . During Phase 3, the clostridia increased to $15.5 \pm 1.6 \%$. These levels of clostridia were considerably lower than those reported by Liu et al. (2002), where Clostridium spp. accounted for $66 \%$ of the total bacterial rRNA. At this coarse level of resolution, a clear impact of tylo- sin on the microbial community structure was not observed, despite changes in reactor performance.

\section{Archaeal Community Structure}

The archaeal community structure was also monitored throughout the reactor operation at a coarse level of resolution using FISH (Figure 1c). The archaea were largely aceticlastic methanogens of the genera Methanosaeta and Methanosarcina (80-100\%). The relative abundance of Methanosaeta prior to the addition of $167 \mathrm{mg} / \mathrm{L}$ tylosin (59\% of total archaea) was comparable to or higher than previous studies (Liu et al., 2002; Zheng et al., 2006). The average abundance of Methanosaeta (normalized to DAPI) began at $15.7 \pm 0.8 \%$ but dropped to $7.6 \pm 0.5 \%$ prior to addition of tylosin and remained relatively stable during addition of $1.67 \mathrm{mg} / \mathrm{L}$ tylosin at $8.4 \pm 0.5 \%$. However, the accumulation of propionate and acetate and decreasing methane production that occurred during the addition of $167 \mathrm{mg} / \mathrm{L}$ tylosin corresponded with a decrease in the Methanosaeta to $3.4 \pm 0.7 \%$ and an increase in Methanosarcina from $2.3 \pm 0.3 \%$ to $7.9 \pm 1.1 \%$.

Tylosin is not expected to target archaea, so this shift in the methanogenic community is presumed to be an indirect effect, perhaps a $\mathrm{pH}$ effect. The accumulation of propionate and acetate caused the $\mathrm{pH}$ to drop to 6.0, below the reported range for growth of Methanosaeta of 6.8-8.2 (Huser et al., 1982) but within the broader reported $\mathrm{pH}$ range of 5.5-8.0 for Methanosarcina (Liu et al., 1985). Additional factors contributing to the shift could include the competitive advantage of Methanosarcina over Methanosaeta at higher acetate concentrations (Jetten et al., 1992), and Methanosarcina's ability to use a broad range of substrates (acetate, hydrogen and $\mathrm{CO}_{2}$, methanol, and methylamines). Further acidification of the reactor resulted in $\mathrm{pH}$ levels of 5.2-5.5, below the optimum for Methanosarcina, and the complete inhibition of acetate uptake (Shimada et al., 2008a).

Some methane production was observed even after acetate uptake ceased. The modeled hydrogen production (Shimada et al., 2008b) was sufficient to produce $8 \%$ methane in the biogas, which corresponded to the measured levels, suggesting that the remaining methane production was due to the utilization of hydrogen.

\section{Phylogenetic Analysis}

To link specific bacterial populations with each stage of the anaerobic food web in the ASBR, clone libraries targeting the bacterial 16S rRNA genes were generated from four biomass samples collected over the three different phases of reactor operation (Table II). With the exception of the second sample collected during 1.67 $\mathrm{mg} / \mathrm{L}$ tylosin addition (day 939), Actinobacteria was the most abundant phylum recovered from the ASBR. The phyla Bacteroidetes, Firmicutes, Nitrospira, and 


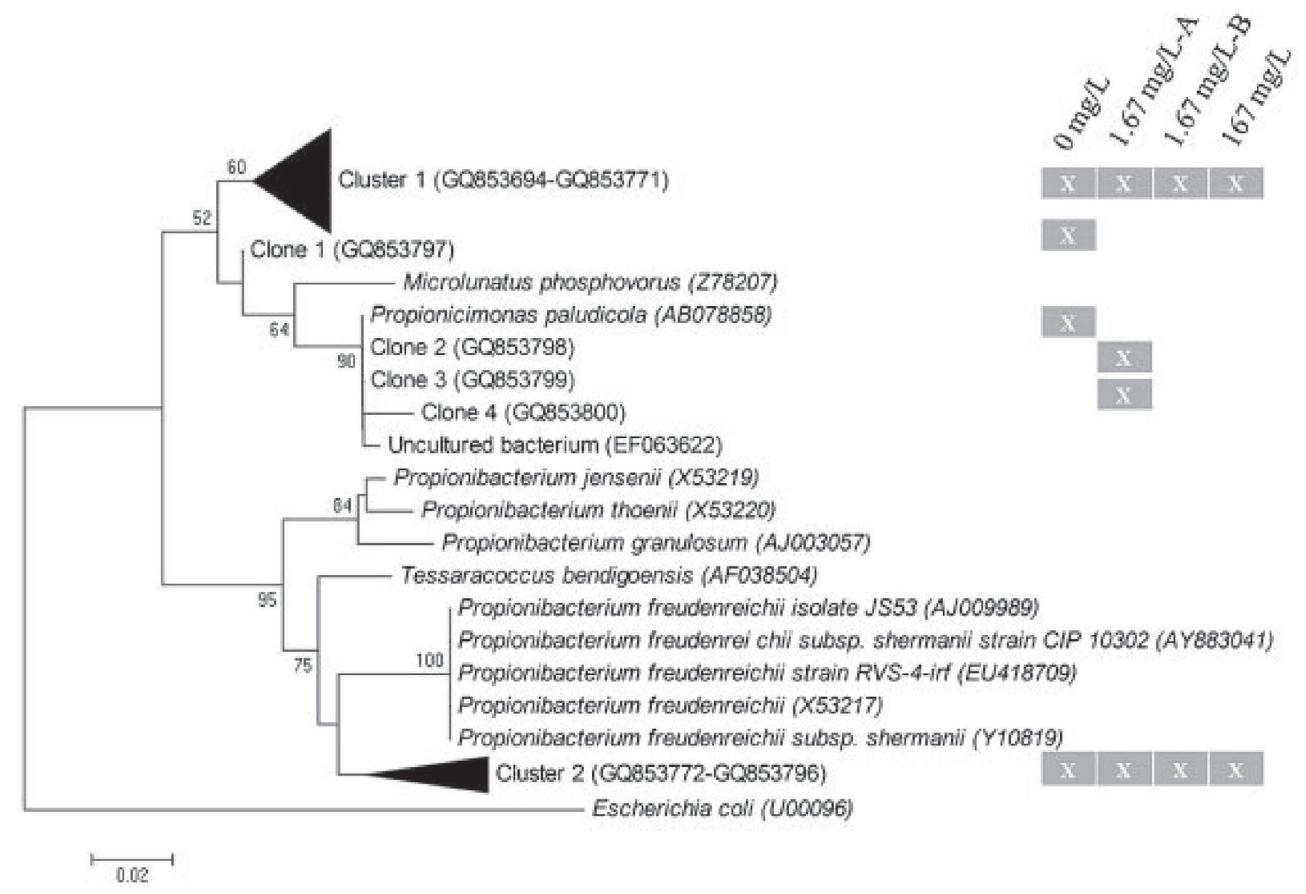
represents 0.02 changes per nucleotide, and the shaded boxes represent presence in the specified clone library.

Proteobacteria were also frequently detected. The addition of $1.67 \mathrm{mg} / \mathrm{L}$ of tylosin corresponded with a considerable decrease in the recovery of sequences from the Firmicutes $(23.2-11.1 \%)$ and increases in sequences related to Actinobacteria (26.3-34.9\%) and Chloriflexi (8.1-12.7\%). Following the addition of $167 \mathrm{mg} / \mathrm{L}$ tylo$\sin$, the recovery of sequences related to Actinobacteria increased to $69.4 \%$ while those related to Bacteroidetes dropped to $2.5 \%$. The dynamics in the recovery of sequences related to Actinobacteria were not observed in the FISH results for the HGC probes, suggesting that any changes in their abundance in the reactor were contained within the HGC group. In general, less diversity was observed following the addition of tylosin.

Among the sequences affiliated to Actinobacteria, several were clustered with the genera Propionibacterium and Propionicimonas $(1.0 \%, 1.6 \%, 0.0 \%$, and $0.8 \%$ of Actinobacteria for days $743,841,939$, and 1,030, respectively). These genera contain fermentative bacteria capable of converting glucose to propionate and acetate and were likely performing that function in our glucosefed reactor. These results confirmed previous work in which, based on high levels of propionate production and transient accumulation of trehalose within the daily cycle, we suggested the presence of glucose fermenting propionibacteria in the ASBR (Shimada et al., 2007). The two major clusters in the phylogenetic tree in Figure 3 include Actinobacteria-affiliated clones from all of the four clone libraries, suggesting that the composition of the Actinobacteria population was relatively stable during the various phases of the reactor operation. With re- spect to tylosin resistance, minimum inhibitory concentrations (MIC) of less than $2 \mathrm{mg} / \mathrm{L}$ tylosin have been reported for sensitive strains of Propionibacterium granulosum, Propionibacterium acnes, and Propionibacterium avidum (Ross et al., 2002), while macrolide resistant strains were not inhibited at concentrations up to $512 \mathrm{mg} / \mathrm{L}$ tylosin (Ross et al., 2002). Our performance results suggest that the populations of Propionibacteriaceae in this reactor were resistant to tylosin.

Propionate uptake has been reported in both Gramnegative (Syntrophobacter and Smithella) and Gram-positive (Desulfotomaculum and Pelotomaculum) organisms (Boone and Bryant, 1980; de Bok et al., 2001; Imachi et al., 2002; Nilsen et al., 1996; Plugge et al., 2002). Because Proteobacteria-related clones from days 743, 841, and 939 were closely related to the genus Syntrophobacter (Figure 4 and Table II) and no clones related to Grampositive propionate utilizers were detected in the clone libraries, propionate uptake in the reactor was attributed to Syntrophobacter. This hypothesis is supported by the results from day 1,030, when propionate accumulated in the reactor and no clones related to Syntrophobacter were recovered (Figure 5 and Table II). However, this is surprising in light of the performance results. Most Gram-negative bacteria are resistant to macrolides due to the relative impermeability of the cellular outer membrane, which functions together with active drug efflux systems (Nikaido, 1996), so if the Gram-negative Syntrophobacter were responsible for propionate uptake then neither the inhibition of propionate uptake observed while $1.67 \mathrm{mg} / \mathrm{L}$ tylosin was being fed nor the 


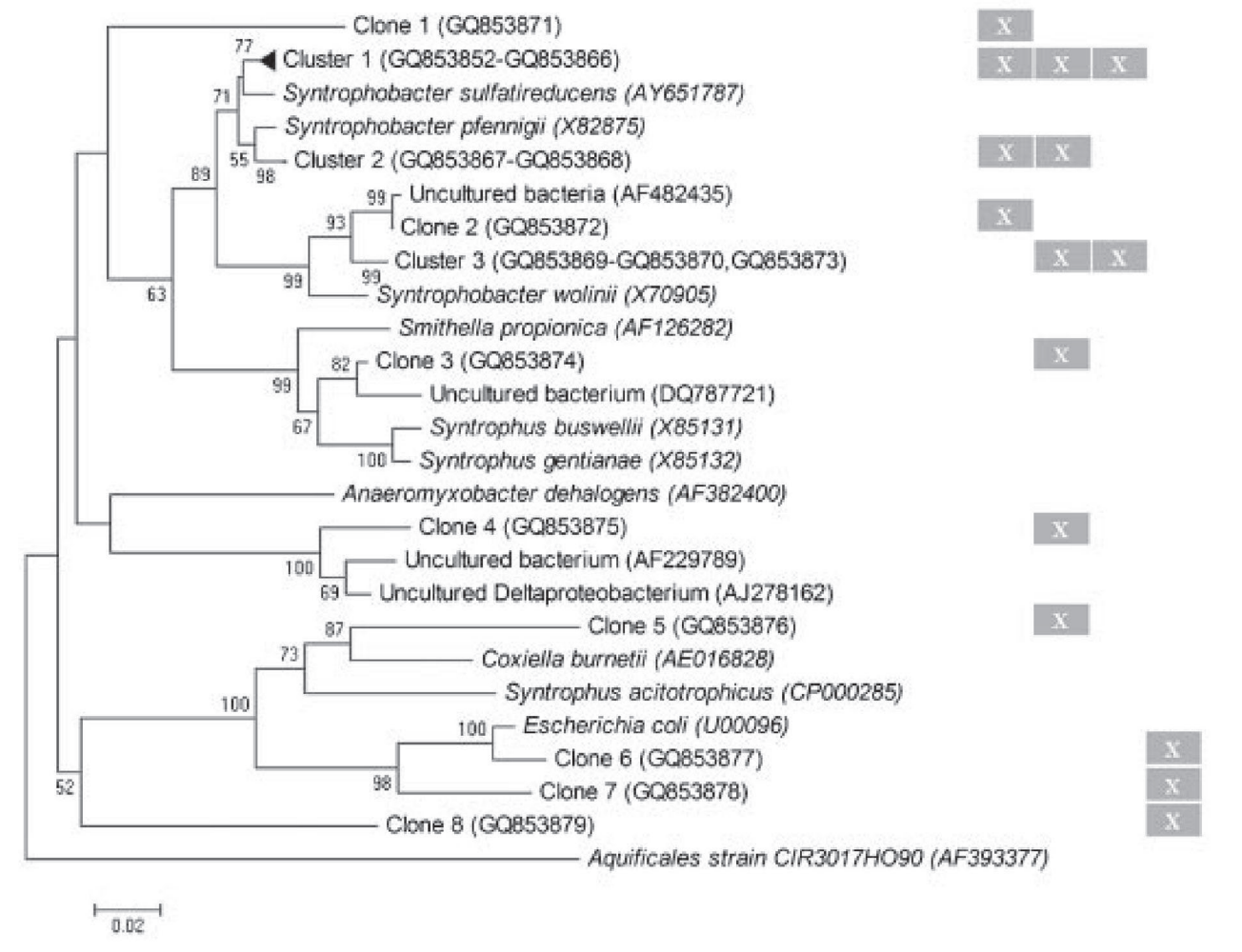

Figure 4. Phylogenetic tree showing the relationship among 1492R-derived sequences affiliated with the phylum Proteobacteria. The scale bar represents 0.02 changes per nucleotide, and the shaded boxes represent presence in the specified clone library.

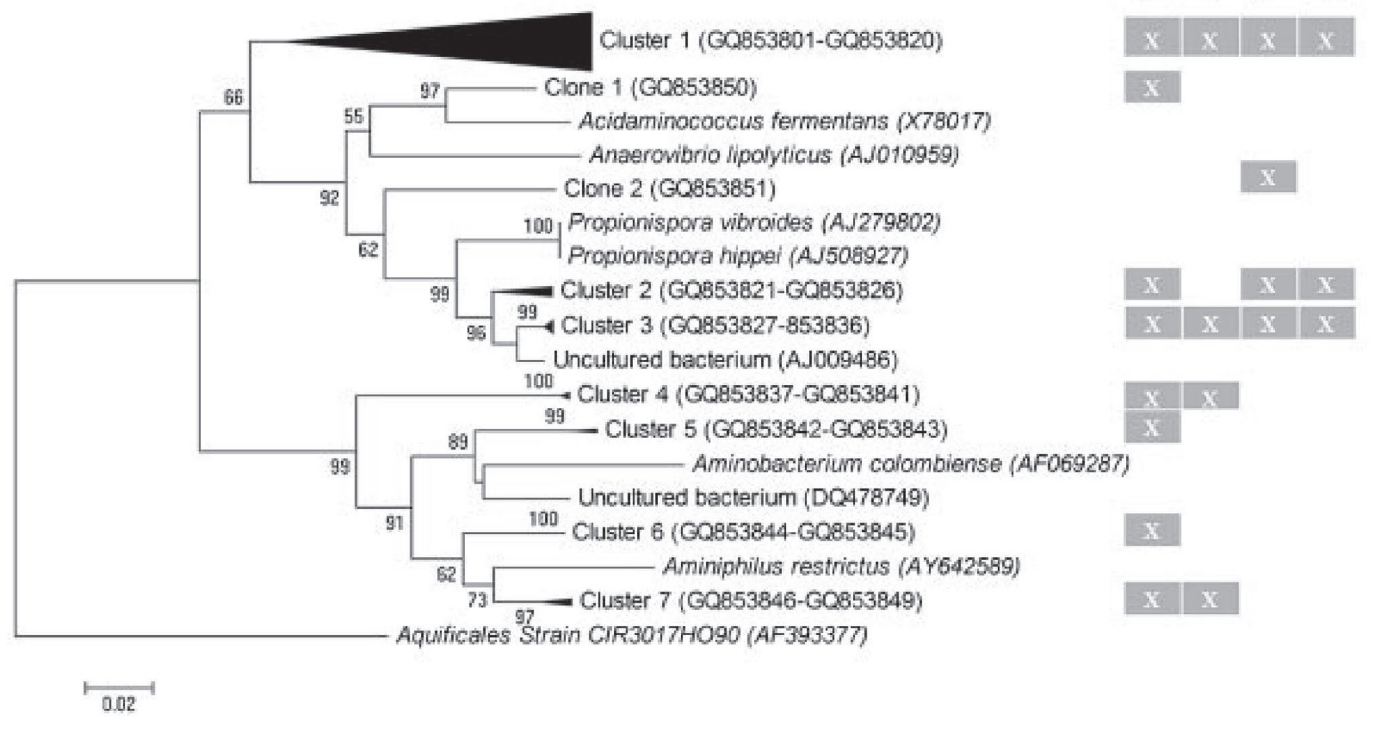

Figure 5. Phylogenetic tree showing the relationship among 1492R-derived sequences affiliated with the phylum Firmicutes. The scale bar represents 0.02 changes per nucleotide, and the shaded boxes represent presence in the specified clone library. 


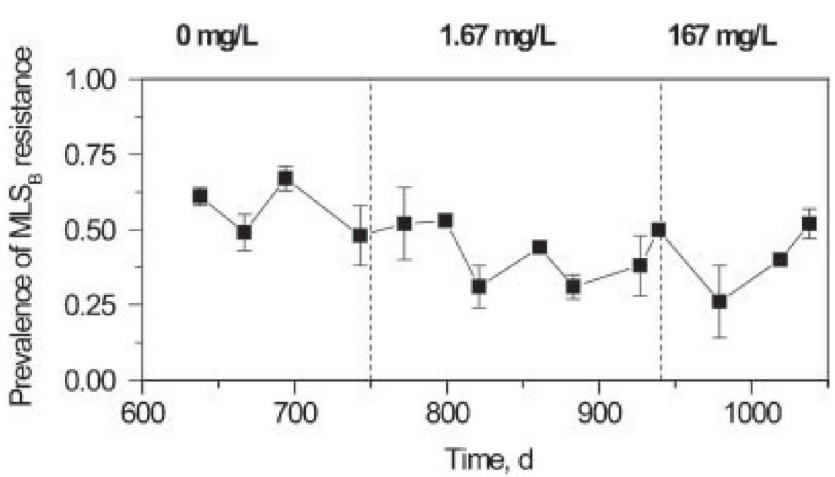

Figure 6. Prevalence of $M L S_{B}$ resistance throughout the operational period. Cells were classified as $M_{L} S_{B}$ resistant if they hybridized to the Bact0338 probe but not to the $\mathrm{MLS}_{B}$ probe, as the same mismatch or site-specific methylation that results in $\mathrm{MLS}_{B}$ resistance prevents hybridization to the $M L S_{B}$ probe. Data points and error bars represent mean values and half ranges of duplicate wells.

observed accumulation of propionate while $167 \mathrm{mg} / \mathrm{L}$ tylosin was being fed would be expected. We were unable to find any reports on the effects of macrolides on Syntrophobacter, but macrolides have been used to treat infections caused by another bacterium of the order Desulfovibrionales, Lawsonia intracellularis (McOrist et al., 1997), so it is reasonable to postulate that Syntrophobacter are also sensitive to macrolides.

The accumulation of acetate when $167 \mathrm{mg} / \mathrm{L}$ tylosin was fed would be expected to create conditions for the growth of homoacetogenic bacteria. However, batch tests performed with ASBR biomass at neutral $\mathrm{pH}$ indicated that acetate uptake was completely inhibited during this period (Shimada et al., 2008a). Furthermore, the level of clones related to Clostridium was below detection in all of the samples except for day 743 , when $5 \%$ of the clones were related to this genus. These results may suggest that tylosin inhibited the homoacetogenic bacteria, and are consistent with work by Amin et al. (2006), in which the partial inhibition of acetate uptake was attributed to direct effects of macrolides (i.e., erythromycin) on homoacetogenic bacteria.

\section{$\mathrm{MLS}_{B}$ Resistance}

The ASBR performance deteriorated during the addition of $167 \mathrm{mg} / \mathrm{L}$ tylosin and did not recover during the operational period considered here, so based on the performance data no increase in tylosin resistance was predicted. The FISH analysis was consistent with the performance-based prediction (Figure 6). Specifically, a slight decrease in the prevalence of cells that hybridized to the bacterial probe but not the $\mathrm{MLS}_{\mathrm{B}}$ probe (presumed MLS $_{\mathrm{B}}$ resistant bacteria) occurred after tylosin addition, from $56.2 \pm 3.9 \%$ in the absence of tylosin to $38.5 \pm 3.2 \%$ and $39.3 \pm 5.9 \%$ under low and high tylosin dosing, respectively (Figure 6). Angenent et al. (2008) reported an increase in $\mathrm{MLS}_{\mathrm{B}}$ resistance in an ASBR treat- ing swine waste but attributed their results to the enrichment with resistant bacteria present in the reactor feed. Occurrence of macrolide resistant organisms in swine waste has been reported previously (Chen et al., 2010; Holzel et al., 2010; Jindal et al., 2006). These results suggest that the development of $\mathrm{MLS}_{\mathrm{B}}$ resistance can be influenced by historical exposure of the seed sludge to antimicrobials and antimicrobial resistant microorganisms and the presence of antimicrobial resistant microorganisms in the influent. The inoculum used in the reactor of the current study had no known exposure to antimicrobials, and the reactor received sterile synthetic wastewater, so these experiments required the development of tylosin resistance rather than monitoring the accumulation of antimicrobial resistance. It is encouraging that resistance did not develop, as a single base pair change can result in $M L S_{B}$ resistance in many organisms. Our data do not exclude the possibility that alternative mechanisms of resistance developed, but any alternative mechanisms that were present were not sufficient to maintain or restore performance.

\section{Modeling}

The overall microbial population dynamics observed in the ASBR were adequately described by the model (Figure 2). The modeled abundance of glucose fermenting bacteria was consistently higher than the measured levels of Actinobacteria, which is likely due to the presence of fermentative bacteria belonging to other phyla, including Firmicutes and Chloriflexi. Aceticlastic methanogens, hydrogen-consuming methanogens, and propionate-oxidizing bacteria levels of up to $30 \%, 10 \%$, and $2 \%$, respectively, were also observed in a glucose-fed upflow anaerobic sludge blanket reactor (Zheng et al., 2006). The 16S rRNA-based quantification used by Zheng et al. (2006) may have underestimated the actual levels of propionate-oxidizing bacteria because the available $16 \mathrm{~S}$ rRNA targeted probes for propionate-oxidizing bacteria may not target all species within this functional group.

\section{Conclusions}

The effects of tylosin vary among different microbial groups of the anaerobic food web. Gram-positive glucose fermenting bacteria (family Propionibacteriaceae) maintained activity in the presence of tylosin concentrations of $167 \mathrm{mg} / \mathrm{L}$. Gram-negative propionate-oxidizing syntrophic bacteria (family Syntrophobacteraceae) and Gram-positive bacteria (genus Clostridium), on the other hand, were detected less frequently after tylosin was introduced. This combination of tylosin resistance in glucose fermenting bacteria and inhibition of propionate or butyrate oxidizing syntrophic bacteria resulted in the accumulation of organic acids in an ASBR. The microbial analysis of a glucose-fed ASBR exposed to different 
concentrations of tylosin showed that the addition of tylosin without the input of antimicrobial resistance genes did not result in an increase in the prevalence of $M S_{B}$ resistance in the reactor.

Acknowledgements - Toshio Shimada was partially supported by a fellowship from the Consejo Nacional de Ciencia y Tecnología (CONACYT), Mexico. This research was supported by the U.S. Department of Agriculture under Cooperative Agreement AG 58-3620-1-179.

\section{References}

Amann RI, Krumholz L, Stahl DA. 1990. Fluorescent-oligonucleotide probing of whole cells for determinative, phylogenetic, and environmental-studies in microbiology. J Bacteriol 172: 762-770.

Amin MM, Zilles JL, Greiner J, Charbonneau S, Raskin L, Morgenroth E. 2006. Influence of the antibiotic erythromycin on anaerobic treatment of a pharmaceutical wastewater. Environ Sci Technol 40: 3971-3977.

Angenent LT, Mau M, Jindal A, George U, Zahn JA, Raskin L. 2008. Effect of the presence of the antimicrobial tylosin in swine waste on anaerobic treatment. Water Res 42(10-11): 2377-2384.

Ashelford KE, Chuzhanova NA, Fry JC, Jones AJ, Weightman AJ. 2006. New screening software shows that most recent large 16S rRNA gene clone libraries contain chimeras. Appl Environ Microbiol 72(9): 5734-5741.

Auerbach T, Bashan A, Yonath A. 2004. Ribosomal antibiotics: Structural basis for resistance, synergism, and selectivity. Trends Biotechnol. 22(11): 570-576.

Batstone DJ, Keller J, Angelidaki I, Kalyuzhnyi SV, Pavlostathis SG, Rozzi A, Sanders WTM, Siegrist H, Vavilin VA. 2002. Anaerobic Digestion Model No. 1. London: IWA Publishing.

Batstone DJ, Keller J, Blackall LL. 2004. The influence of substrate kinetics on the microbial community structure in granular anaerobic biomass. Water Res 38: 1390-1404.

Boone DR, Bryant MP. 1980. Propionate-degrading bacterium, Syntrophobacter-Wolinii Sp-Nov Gen-Nov from Methanogenic Ecosystems. App Environ Microbiol 40: 626-632.

Campagnolo ER, Johnson KR, Karpati A, Rubin CS, Koplin DW, Meyer MT, Esteban JE, Currier RW, Smith K, Thu K, McGeehin M. 2002. Antimicrobial residues in animal waste and water resources proximal to large-scale swine poultry feeding operations. Sci Total Environ 299: 89-95.

Camprubi MJ, Paris M, Casas C. 1988. Effects of antimicrobial agents and feed additives on the performance of piggery waste anaerobic treatment. In HobsonPN, editor. 5th International Symposium on Anaerobic Digestion. Bologna, Italy: Pergamon Press, p 239-248.

Chelliapan S, Wilby T, Sallis PJ. 2006. Performance of an upflow anaerobic stage reactor (UASR) in the treatment of pharmaceutical wastewater containing macrolide antibiotics. Water Res 40: 507-516.

Chen J, Michel FC, Jr., Sreevatsan S, Morrison M, Yu Z. 2010. Occurrence and persistence of erythromycin resistance genes (erm) and tetracycline resistance genes (tet) in waste treatment systems on swine farms. Microb Ecol, doi: 10.1007/s00248-010-9634-5.

Chenna R, Sugawara H, Koike T, Lopez R, Gibson TJ, Higgins DG, Thompson JD. 2003. Multiple sequence alignment with the Clustal series of programs. Nucleic Acids Res 31(13): 3497-3500.

Cole JR, Chai B, Farris RJ, Wang Q, Kulam-Syed-Mohideen AS, McGarrell DM, et al. 2007. The ribosomal database project (RDP-II): Introducing myRDP space and quality controlled public data. Nucleic Acids Res 35: D169-D172.

Daims H, Brühl A, Amann R, Schleifer KH, Wagner M. 1999. The domain-specific probe EUB338 is insufficient for the detection of all Bacteria: Development and evaluation of a more comprehensive probe set. Sys Appl Microbiol 22: 434-444.

de Bok FA, Stams AJ, Dijkema C, Boone DR. 2001. Pathway of propionate oxidation by a syntrophic culture of Smithella propionica and Methanospirillum hungatei. Appl Environ Microbiol 67: 1800-1804.

De los Reyes FL, Ritter W, Raskin L. 1997. Group-specific small-subunit rRNA hybridization probes to characterize filamentous foaming in activated sludge systems. Appl Environ Microbiol 63: 1107-1117.

Dojka MA, Harris JK, Pace NR. 2000. Expanding the known diversity and environmental distribution of an uncultured phylogenetic division of bacteria. Appl Environ Microbiol 66: 1617-1621.

Fields MW, Yan TF, Rhee SK, Carroll SL, Jardine PM, Watson DB, Criddle CS, Zhou JZ. 2005. Impacts on microbial communities and cultivable isolates from groundwater contaminated with high levels of nitric acid-uranium waste. FEMS Microbiol Ecol 53(3): 417-428.

Garza-Ramos G, Xiong L, Zhang P, Mankin A. 2001. Binding site of macrolide antibiotics on the ribosome: New resistance mutation identifies a specific interaction of kelotides with rRNA. J Bacteriol 183(23): 6898-6907.

Hall TA. 1999. BioEdit: A user-friendly biological sequence alignment editor and analysis program for Windows 95/98/NT. Nucleic Acids Symp Ser 41: 95-98.

Holzel CS, Schwaiger K, Harms K, Kuchenhoff H, Kunz A, Meyer K, Muller C, Bauer J. 2010. Sewage sludge and pig manure as possible sources of antibiotic resistant bacteria. Environ Res 110: 318-326.

Huser BA, Wuhrmann K, Zehnder AJB. 1982. Methanothrix soehngenii gen. nov. sp. Nov., a new acetotrophic non-hydrogen-oxidizing methane bacterium. Arch Microbiol 132: 1-9.

Imachi H, Sekiguchi Y, Kamagata Y, Hanada S, Ohashi A, Harada H. 2002. Pelotomaculum thermopropionicum gen. nov., sp nov., an anaerobic, thermophilic, syntrophic propionate-oxidizing bacterium. Int J Syst Evol Microbiol 52: 1729-1735.

Jensen LB, Frimodt-Moller N, Aarestrup FM. 1999. Presence of erm gene classes in Gram-positive bacteria of animal and human origin in Denmark. FEMS Microbiol Lett 170: 151-158.

Jetten MSM, Stams AJM, Zehnder AJB. 1992. Methanogenesis from acetate: A comparison of the acetate metabolism in Methanothrix soehngenii and Methanosarcina spp. FEMS Microbiol Lett 84(3-4): 181-197. 
Jindal A, Kocherginskaya S, Mehboob A, Robert M, Mackie RI, Raskin L, Zilles JL. 2006. Antimicrobial resistance in swine waste treatment systems. Appl Environ Microbiol 72: 7813-7820.

Koplin DW, Furlong ET, Meyer MT, Thurman EM, Zaugg SD, Barber LB, Buxton HT. 2002. Pharmaceuticals, hormones, and other organic wastewater contaminants in U.S. streams, 1999-2000: A national reconnaissance. Environ Sci Technol 36: 1202-1211.

Kummerer K. 2001. Drugs in the environment: Emission of drugs, diagnostic aids and disinfectants into wastewater by hospitals in relation to other sources-A review. Chemosphere 45: 957-969.

Liu Y, Boone DR, Sleat R, Mah RA. 1985. Methanosarcina mazei LYC a new methanogenic isolate which produces a disaggregating enzyme. Appl Environ Microbiol 49(3): 608-613.

Liu WT, Chan OC, Fang HHP. 2002. Characterization of microbial community in granular sludge treating brewery wastewater. Water Res 36: 1767-1775.

Loftin KA, Henny C, Adams CD, Surampali R, Mormile MR. 2005. Inhibition of microbial metabolism in anaerobic lagoons by selected sulfonamides, tetracyclines, lincomycin, and tylosin tartrate. Environ Toxicol Chem 24: 782-788.

Masse DI, Lu D, Masse L, Droste RL. 2000. Effect of antibiotics on psychrophilic anaerobic digestion of swine manure slurry in sequencing batch reactors. Bioresource Technol 75: 205-211.

McGuire JM, Boniece WC, Higgens CE, Hoehn MM, Stark WM, Westhead J, Wolfe RN. 1961. Tylosin, a new antibiotic: I Microbiological studies. Antibiot Chemother 11: 320.

McOrist S, Morgan J, Veenhuizen MF, Lawrence K, Kroger HW. 1997. Oral administration of tylosin phosphate for treatment and prevention of proliferative enteropathy in pigs. Am J Vet Res 58: 136-139.

Nikaido H. 1996. Multidrug efflux pumps of gram-negative bacteria. J Bacteriol 178: 5853-5859.

Nilsen RK, Torsvik T, Lien T. 1996. Desulfotomaculum thermocisternum sp nov., a sulfate reducer isolated from a hot North Sea oil reservoir. Int J Syst Bacteriol 46(2): 397-402.

Plugge CM, Balk M, Stams AJM. 2002. Desulfotomaculum thermobenzoicum subsp thermosyntrophicum subsp nov., a thermophilic, syntrophic, propionate-oxidizing, sporeforming bacterium. Int J Syst Evol Microbiol 52: 391-399.

Poels J, Vanassche P, Verstraete W. 1984. Effects of disinfectants and antibiotics on the anaerobic-digestion of piggery waste. Agric Wastes 9: 239-247.

Raskin L, Poulsen LK, Noguera DR, Rittmann BE, Stahl DA. 1994. Quantification of methanogenic groups in anaerobic biological reactors by oligonucleotide probe hybridization. Appl Environ Microbiol 60: 1241-1248.

Reichert P. 1994. Aquasim-A tool for simulation and dataanalysis of aquatic systems. Water Sci Technol 30: 21-30.

Richardson RE, Bhupathiraju VK, Song DL, Goulet TA, Alvarez-Cohen L. 2002. Phylogenetic characterization of microbial communities that reductively dechlorinate TCE based upon a combination of molecular techniques. Environ Sci Technol 36: 2652-2662.
Roller C, Wagner M, Amann R, Ludwig W, Schleifer KH. 1994. In situ probing of gram-positive bacteria with high DNA $\mathrm{G}+\mathrm{C}$ content using 23S rRNA-targeted oligonucleotides. Microbiology 140(Pt 10): 2849-2858.

Ross JI, Eady EA, Carnegie E, Cove JH. 2002. Detection of transposon Tn5432-mediated macrolide-lincosamidestreptogramin B $\left(\mathrm{MLS}_{\mathrm{B}}\right)$ resistance in cutaneous propionibacteria from six European cities. J Antimicrob Chemother 49: 165-168.

Sanz JL, Rodriguez N, Amils R. 1996. The action of antibiotics on the anaerobic digestion process. Appl Microbiol Biotechnol 46: 587-592.

Sekiguchi Y, Kamagata Y, Syutsubo K, Ohashi A, Harada H, Nakamura K. 1998. Phylogenetic diversity of mesophilic and thermophilic granular sludges determined by $16 \mathrm{~S}$ rRNA gene analysis. Microbiology 144: 2655-2665.

Shimada T, Zilles JL, Morgenroth E, Raskin L. 2007. Carbohydrate storage in anaerobic sequencing batch reactors. Water Res 41(20): 4721-4729.

Shimada T, Zilles JL, Morgenroth E, Raskin L. 2008a. Effects of tylosin on the performance of anaerobic sequencing batch reactors. Biotechnol Bioeng 101(1): 73-82.

Shimada T, Zilles JL, Morgenroth E, Raskin L. 2008b. Modeling the effects of tylosin on anaerobic sequencing batch reactors. Water Sci Technol 57(11): 1699-1704.

Stahl DA, Amann RI. 1991. Development and application of nucleic acid probes. In: GoodfellowM, editor. Nucleic acid techniques in bacterial systematics, New York: Wiley. p 206-248.

Stone JJ, Clay SA, Zhu Z, Wong KL, Porath LR, Spellman GM. 2009. Effect of antimicrobial compounds tylosin and chlortetracycline during batch anaerobic swine manure digestion. Water Res 43(18): 4740-4750.

Tamura K, Dudley J, Nei M, Kumar S. 2007. MEGA4: Molecular evolutionary genetics analysis (MEGA) software version 4.0. Mol Biol Evol 24(8): 1596-1599.

Weber S, Stubner S, Conrad R. 2001. Bacterial populations colonizing and degrading rice straw in anoxic paddy soil. Appl Environ Microbiol 67: 1318-1327.

Weisblum B. 1995. Erythromycin resistance by ribosome modification. Antimicrob Agents Chemother 39: 577-585.

Zheng DD, Angenent LT, Raskin L. 2006. Monitoring granule formation in anaerobic upflow bioreactors using oligonucleotide hybridization probes. Biotechnol Bioeng 94: 458-472.

Zhou Z, Pons MN, Raskin L, Zilles JL. 2007. Automated image analysis for quantitative fluorescence in situ hybridization with environmental samples. Appl Environ Microbiol 73: 2956-2962.

Zhou Z, Raskin L, Zilles J. 2009. Identification of macrolide resistant organisms on antimicrobial-free swine farms. Appl Environ Microbiol 75(18): 5814-5820.

Zilles J, Shimada T, Jindal A, Robert M, Raskin L. 2005. Presence of macrolide-lincosamide-streptogramin B and tetracycline antimicrobials in swine waste treatment processes and amended soil. Water Environ Res 77: 57-62. 
APPENDIX

Table A1: Model Parameters

\begin{tabular}{|c|c|c|c|}
\hline Parameter & Value & Units & Source \\
\hline $\mathrm{k}_{\mathrm{m}, \mathrm{su}}$ & 30 & $\mathrm{~g} \mathrm{COD} /(\mathrm{g} \mathrm{COD} \mathrm{d})$ & 1 \\
\hline $\mathrm{K}_{\mathrm{s}, \mathrm{su}}$ & 0.5 & $\mathrm{~g} \mathrm{COD} / \mathrm{L}$ & 1 \\
\hline$Y_{\mathrm{su}}$ & 0.1 & g COD/g COD & 1 \\
\hline$f_{\text {pro,su }}$ & 0.47 & $\mathrm{~g}$ COD/g COD & 2 \\
\hline $\mathrm{f}_{\mathrm{ac}, \mathrm{su}}$ & 0.13 & $\mathrm{~g} \mathrm{COD} / \mathrm{g}$ COD & 2 \\
\hline $\mathrm{f}_{\mathrm{h} 2, \mathrm{su}}$ & 0.0 & $\mathrm{~g} \mathrm{COD} / \mathrm{g}$ COD & 2 \\
\hline $\mathrm{f}_{\mathrm{bu}, \mathrm{su}}$ & 0.0 & $\mathrm{~g} \mathrm{COD} / \mathrm{g}$ COD & 2 \\
\hline$f_{\text {sto,su }}$ & 0.40 & $\mathrm{~g} \mathrm{COD} / \mathrm{g}$ COD & 2 \\
\hline $\mathrm{k}_{\text {hyd,sto }}$ & 4 & $\mathrm{~g} \mathrm{COD} /(\mathrm{g} \mathrm{COD} \mathrm{d})$ & 2 \\
\hline $\mathrm{k}_{\mathrm{m}, \mathrm{pro}}$ & 12.6 & $\mathrm{~g} \mathrm{COD} /(\mathrm{g} \mathrm{COD} \mathrm{d})$ & 3 \\
\hline $\mathrm{K}_{\mathrm{s} \text {,pro }}$ & 0.3 & $\mathrm{~g} \mathrm{COD} / \mathrm{L}$ & 1 \\
\hline$Y_{\text {pro }}$ & 0.04 & $\mathrm{~g} \mathrm{COD} / \mathrm{g}$ COD & 1 \\
\hline $\mathrm{k}_{\mathrm{m} \text {,ace }}$ & 16 & $\mathrm{~g} \mathrm{COD} /(\mathrm{g} \mathrm{COD} \mathrm{d})$ & 3 \\
\hline $\mathrm{K}_{\mathrm{s} \text {,ace }}$ & 0.15 & $\mathrm{~g} \mathrm{COD} / \mathrm{L}$ & 1 \\
\hline $\mathrm{Y}_{\text {ace }}$ & 0.05 & $\mathrm{~g} \mathrm{COD} / \mathrm{g}$ COD & 1 \\
\hline $\mathrm{k}_{\mathrm{m}, \mathrm{h} 2}$ & 35 & $\mathrm{~g} \mathrm{COD} /(\mathrm{g} \mathrm{COD} \mathrm{d})$ & 1 \\
\hline $\mathrm{K}_{\mathrm{s}, \mathrm{h} 2}$ & $2.5 \times 10^{-5}$ & $\mathrm{~g} \mathrm{COD} / \mathrm{L}$ & 1 \\
\hline $\mathrm{Y}_{\mathrm{h} 2}$ & 0.06 & $\mathrm{~g} \mathrm{COD} / \mathrm{g} \mathrm{COD}$ & 1 \\
\hline $\mathrm{k}_{\mathrm{dec}, \mathrm{su}}$ & 0.02 & $1 / \mathrm{d}$ & 2 \\
\hline $\mathrm{k}_{\mathrm{dec}, \text { pro }}$ & 0.01 & $1 / \mathrm{d}$ & 2 \\
\hline $\mathrm{k}_{\text {dec,ace }}$ & 0.005 & $1 / \mathrm{d}$ & 2 \\
\hline $\mathrm{k}_{\mathrm{dec}, \mathrm{h} 2}$ & 0.01 & $1 / d$ & 2 \\
\hline $\mathrm{k}_{\mathrm{tyl}}$ & 0.011 & & 3 \\
\hline $\mathrm{K}_{\mathrm{F}}$ & 40 & & 4 \\
\hline $\mathrm{n}$ & 1.32 & & 4 \\
\hline $\mathrm{K}_{\mathrm{I} \text {,pro }}$ & 3 & $\mathrm{~g} \mathrm{COD} / \mathrm{L}$ & 3 \\
\hline $\mathrm{K}_{\mathrm{I} \text {,ace }}$ & 1 & $\mathrm{~g} \mathrm{COD} / \mathrm{L}$ & 3 \\
\hline $\mathrm{K}_{\mathrm{I}, \mathrm{tyl}}$ & 0.1 & $\mathrm{mg} / \mathrm{L}$ & 3 \\
\hline $\mathrm{K}_{\mathrm{I}, \mathrm{NH} 3}$ & 0.0018 & $\mathrm{~mol} / \mathrm{L}$ & 1 \\
\hline $\mathrm{K}_{\mathrm{I}, \mathrm{su}}$ & 0.1 & $\mathrm{~g} \mathrm{COD} / \mathrm{L}$ & 2 \\
\hline $\mathrm{K}_{\mathrm{I}, \mathrm{h} 2}$ & $1 \times 10^{-7}$ & $\mathrm{~g} \mathrm{COD} / \mathrm{L}$ & 3 \\
\hline
\end{tabular}

Sources: (1) ADM1 suggested parameters (Batstone et al., 2002); (2) ADM1 parameters for microbial storage and carbohydrate hydrolysis (Shimada et al., 2007), Appendix A); (3) Estimated based on experimental data; (4) Freundlich coefficient $\left(\mathrm{K}_{\mathrm{F}}\right)$ and non-linearity parameter (n) for tylosin in lagoons (Kolz et al., 2005) 